www.jmscr.igmpublication.org

Impact Factor (SJIF): 6.379

Index Copernicus Value: 71.58

ISSN (e)-2347-176x ISSN (p) 2455-0450

crossref DOI: _https://dx.doi.org/10.18535/jmscr/v6i3.174

Journal Of Medical Science And Clinical Research

\title{
Radical Chemoradiation and intraluminal brachytherapy boost in Squamous cell carcinoma of the Esophagus
}

\author{
Authors \\ Dr Arun Sankar Sudha MD, Dr Rakesh Kapoor MD $^{2}$, Dr Rakesh Kochhar DM ${ }^{3}$ \\ ${ }^{1}$ Division of Radiation oncology, Regional Cancer Centre, Thiruvananthapuram, Kerala, India \\ ${ }^{2}$ Department of Radiotherapy, PGIMER, Chandigrah, India \\ Email: rkapoor.r@gmail.com \\ ${ }^{3}$ Department of Gastroenterology, PGIMER, Chandigarh, India \\ Corresponding Author \\ Dr Arun Sankar Sudha, MD \\ Division of Radiation oncology, Regional Cancer Centre, Thiruvananthapuram, Kerala, India \\ Email:drarunssankar@gmail.com,arunsank@gmail.com, Phone: +91-9249554405
}

\begin{abstract}
Aim \& Objective: To report the toxicity and outcome of intraluminal brachytherapy(ILBT) boost following chemoradiation (CRT) in the radical treatment of patients with Squamous cell carcinoma of the esophagus.
\end{abstract}

Patients \& Methods: Patients with non-metastatic squamous cell carcinoma of the esophagus who were not candidates for surgery, were enrolled for this prospective observational study. They were treated with external radiation (44 Gy in 2Gy/day) with concurrent weekly cisplatin and 5-fluorouracil followed by brachytherapy boost. Acute and late toxicities, local control and overall survival were analyzed.

Result: Thirty patients with mean age of 53 years were enrolled in this study. Mean length of esophagus involved was $6 \mathrm{~cm}$. Two (6.6\%) patients experienced grade 3 event-esophagitis, while 4(13.3\%) patients developed esophageal perforation, of which 2 patients had gross residual disease, while two patients were locally disease free. Two patients (6.6\%)died due to treatment related causes - esophageal perforation. Three $(10 \%)$ patients developed grade3 stricture and symptomatic ulcers which required serial esophageal dilatation. Complete response as assessed at 3 months was 76.6\%. The disease free survival and the overall survival at 1 year was $65.4 \%$ and $74.8 \%$ respectively.

Conclusion: In patients with Squamous cell carcinoma of the esophagus, radical chemoradiation with brachytherapy boost is well tolerated, with low incidence of severe complications and offers good survival.

Keywords: Esophageal neoplasms, Chemoradiotherapy, Brachytherapy, Squamous cell carcinoma.

\section{Introduction}

Oesophageal cancer is the eighth most common cancer worldwide, and the sixth most common cause of death from cancer. In India, it is the seventh most common cancer with an estimated incidence of 41800 cases $^{(1)}$. Presently, the standard of care treatment for carcinoma of the esophagus is neo-adjuvant chemoradiation 
(NACTRT) followed by surgery, the other options being neo-adjuvant chemotherapy (NACT) followed by surgery and radical chemoradiation (CTRT). For a significant number of the patients who are not candidates for surgery due to various reasons such as locally advanced nature of disease, frail general health, medical comorbidities, unwillingness for surgery and unavailability of surgical experts, radical chemoradiation is the treatment of choice.

Recently, the additional benefit of surgery in the clinical complete responders following neoadjuvant CRT for SCC of esophagus has been questioned $^{(2)}$. In the CROSS trial, $49 \%$ of patients with Squamous cell carcinoma achieved complete pathological response with NACTRT, for whom the addition of surgery may be unnecessary ${ }^{(3)}$. However, after radical chemoradiation local/regional failure and persistence of disease occurs in $50-55 \%$ of patients ${ }^{(4)}$.

The optimal dose of radiation is controversial, with INT 0123 trial showing no significant benefit in dose escalation to $64.8 \mathrm{~Gy}$ compared to $50.4 \mathrm{~Gy}^{(4)}$. However, more recent trials on multimodality approaches have successfully scheduled doses of more than 50Gy without excess morbidity ${ }^{(5,6)}$. Dose escalation using external beam radiation may result in significant dose to the lung and the heart, thereby increasing the morbidity and mortality and offsetting any advantage in the cure rates. In this context, intraluminal brachytherapy (ILBT) offers the advantage of higher doses to the tumor, while sparing adjacent normal tissues and has been studied using a variety of schedules across the world $^{(7)}$. This study reports the outcome of patients who were treated with radical chemoradiation and intraluminal brachytherapy boost.

\section{Patients and Methods}

Untreated patients with Squamous cell carcinoma of the esophagus who were unfit or not willing for surgery was taken up for this prospective observational study.

\section{Eligibility criteria}

Patients aged 70 or less, with locally advanced disease (cT3-4, N0-1,M0) and length of esophageal involvement less than $10 \mathrm{~cm}$ were qualified for the study. Additional eligibility criteria included normal baseline liver, renal and bone marrow functions. All patients underwent endoscopic assessment and computed tomogram for assessing the extent of disease. Patients with involvement of cervical esophagus, gastroesophageal junction as well as invasion of tracheabronchial tree and tight esophageal stenosis across which endoscope cannot be negotiated were excluded.

Treatment: All patients received external beam radiation with concurrent chemotherapy followed by brachytherapy boost after a break of 2 weeks. Chemotherapy: Concurrent chemotherapy was given only with external radiation and consisted of weekly cycles of Cisplatin $30 \mathrm{mg} / \mathrm{m}^{2}$ with $5-\mathrm{FU}$ $325 \mathrm{mg} / \mathrm{m}^{2}$.

Radiation therapy: External beam radiation was delivered with megavoltage photon beams either on Cobalt $^{60}$ teletherapy unit or $6 \mathrm{MV}$ linear accelerator to a total dose of $44 \mathrm{~Gy}$ at $2 \mathrm{~Gy}$ per fraction. Parallel opposed fields were used, which covered the gross tumor with $5 \mathrm{~cm}$ margin longitudinally and $2 \mathrm{~cm}$ laterally. The dose was prescribed to the midplane, lung inhomogeniety correction was not used. Intraluminal brachytherapy was performed 2weeks after completion of external radiation. Endoscopy was done for assessing the extent of disease and response to chemoradiation. The Selectron bougie with diameter of $1 \mathrm{~cm}$ was threaded over a guide wire and positioned such that its lower end was $2 \mathrm{~cm}$ beyond the initial extent of the lesion. Brachytherapy dose of $12 \mathrm{~Gy}$ in 2 sessions or $14 \mathrm{~Gy}$ in 3 sessions were prescribed at $1 \mathrm{~cm}$ from central axis of the source as per the American Brachytherapy consensus guidelines. The patients were treated using high dose rate Microselectron, with maximum activity of 10 Curie, with the sessions delivered one week apart. The total BED was $109 \mathrm{~Gy}_{3}$. 


\section{Follow-up}

Patients were followed up at end of 1, 2, 3 months, bi-monthly in the first year and every 4months thereafter. At each visit, patients underwent complete clinical examination and assessment of symptom relief and radiation morbidity. Barium swallows were done at $1^{\text {st }}, 3^{\text {rd }}$, $7^{\text {th }}$ months and endoscopic examination at $3^{\text {rd }}$ month. Additional tests were done when clinically justified. Endoscopic biopsy was done at $3^{\text {rd }}$ month to assess the local response.

\section{Assessment of tumor control}

Complete response was defined as complete disappearance of endoscopically visible disease and absence of malignant cells on biopsy or brush smear cytology. Partial response was defined as reduction of tumor mass by $50 \%$, no new areas of tumor development and minimal response was reduction of tumor size $<50 \%$. Progressive disease was defined as increase in the size of tumor by more than $25 \%$ or appearance of new lesions.

The acute radiation morbidity, relevant from day 1 to day 90 was assessed using the Common Terminology Criteria for Adverse Events (CTCAE) version 3 (58) and thereafter the late complication was assessed using the respective RTOG/EORTC criteria

\section{Statistical Analysis}

The major end points of this study were - local disease free status, overall survival and treatment related acute and late toxicity. Statistical analysis of difference of means of parametric variables was done by the Chi square test and the discreet variables by the unpaired $\mathrm{T}$ test. Correlations between categorical variables were performed with the Spearman's test and those between discrete variables with Pearson's test. Survival analysis and actuarial probabilities were calculated with the Kaplan Meier test and the log rank test used for performing univariate analysis for factors predictive of local control and disease free survival. Cox proportional hazards model was used for multivariate analysis. All $\mathrm{P}$ values were two sided and a $\mathrm{P}$ value less than 0.05 were taken as significant.

\section{Results}

Thirty patients were enrolled in this study, with a mean age of 53 years (range 30-70yrs) and majority being males (3.3:1). All patients had Squamous cell carcinoma of the esophagus. The site of the lesion was upper thoracic in one, lower thoracic in seven and middle thoracic in the remaining patients. The mean length of the lesion was $6 \mathrm{~cm}(3-9 \mathrm{~cm})$ and the thickness of lesion $1.4 \mathrm{~cm}(0.9-2.5 \mathrm{~cm})$. The patients had a mean initial weight loss of $6 \mathrm{~kg}$ prior to treatment (Table 1).

All patients completed the planned external radiation without any breaks. Patients received a median 4 cycles of concurrent chemotherapy with a median relative dose intensity of 0.76 . Intraluminal brachytherapy was delivered as planned for 28 patients; one patient refused further treatment after external radiation while the second patient expired after one session of brachytherapy. Gross disease (poor response), defined as more than $3 \mathrm{~cm}$ residual disease, at the time of brachytherapy was present in $8(29 \%)$ patients. The mean overall treatment time was 60 days. Toxicity

The most commonly experienced toxicity was vomiting, dysphagia due to esophagitis and leucocytopenia. Vomiting was seen in $70 \%$ of the patients, however grade 2 and 3 vomiting was seen in only 3 patient s(Table 2$)$. Two $(6.6 \%)$ patients experienced grade 3 event - esophagitis, while $4(13.3 \%)$ patients developed esophageal perforation, of which 2 patients had gross residual disease, while two patients were locally disease free. Two patients $(6.6 \%)$ died due to treatment related causes - esophageal perforation. Three (10\%) patients developed grade3 stricture and symptomatic ulcers which required serial esophageal dilatation. Cardiac toxicity in the form of asymptomatic ECG changes (grade 1) was seen in 6 patients $(20 \%)$. None had any higher grades of cardiac toxicity. Pulmonary toxicity in the form of mild cough, or exertional dyspnea (grade 1) was seen in 2 patients in each arm (13.3\%). A higher grade of lung toxicity was not observed (Table 3). 


\section{JMSCR Vol||06||Issue||03||Page 1051-1058||March}

\section{Local Control and Survival}

Complete response as assessed at 3 months was $76.6 \%$. The local control rate at 1 year was $61.7 \%$. Seven patients had persistence of local disease, of which two patients developed distant metastasis also. Two patients developed local recurrence and one patient had distant metastasis alone during follow-up. The disease free survival and the overall survival at 1 year was $65.4 \%$ and $74.8 \%$ respectively (Fig 1A\&1B).

\section{Prognostic and Predictive factors}

In univariate analysis, the extent of response to initial chemoradiation was found to be significant predictor for both local control and overall survival $(\mathrm{p}=0.001)$. Other factors examined such as age, sex, length of esophageal involvement,

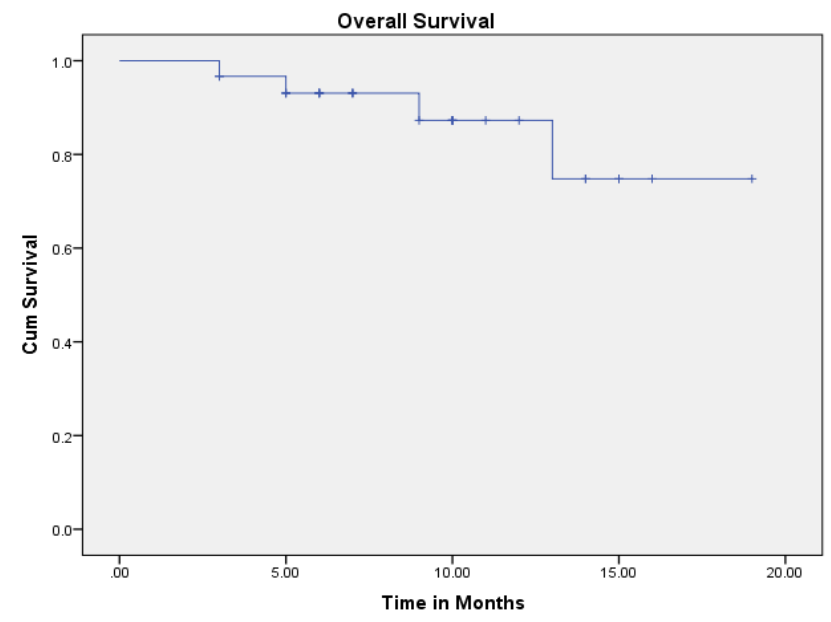

initial weight loss or number of chemotherapy cycles, were not found to be significant(Fig 2A\&2B).

\section{Swallowing functions \& Weight gain}

Dysphagia before treatment was graded as grade 1 in 4 patients, grade 2 in 22, grade 3 in 4 and grade 4 in 0 patients. At 3 months follow up the dysphagia had improved in $24(80 \%)$ patients and unchanged in $4(13.3 \%)$ patients ( 1 patient expired and 1 absconded while on treatment). The 3 month post treatment weight was also assessed and weight gain or weight loss was defined as a 3 month post- to pre-treatment weight of $\leq 5 \%$ or $>5 \%$ respectively. It was categorized as weight loss in 11 patients $(36.7 \%)$, a gain in 6 patients $(20 \%)$ and stable in 11 patients $(36.7 \%)$.

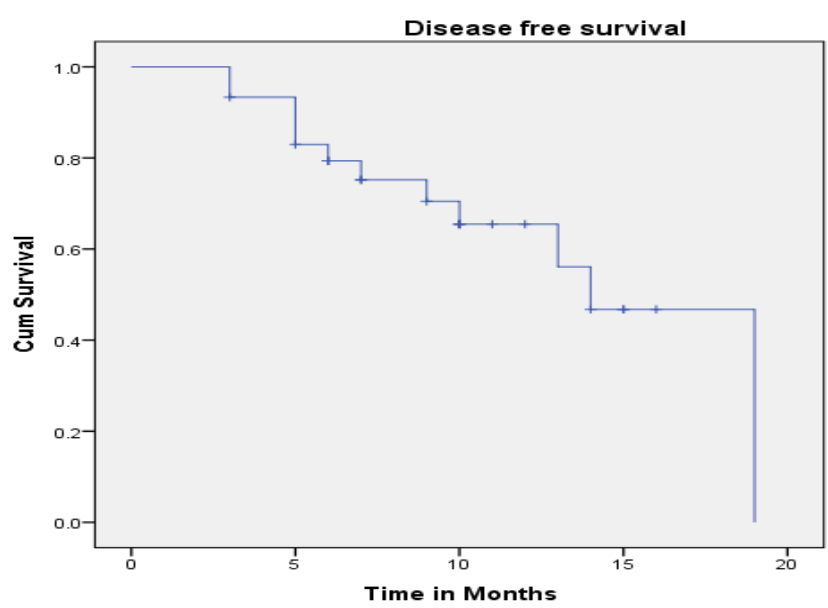

Fig 1A \& 1B. Kaplan Meier Plots showing Overall Survival and Disease free Survival
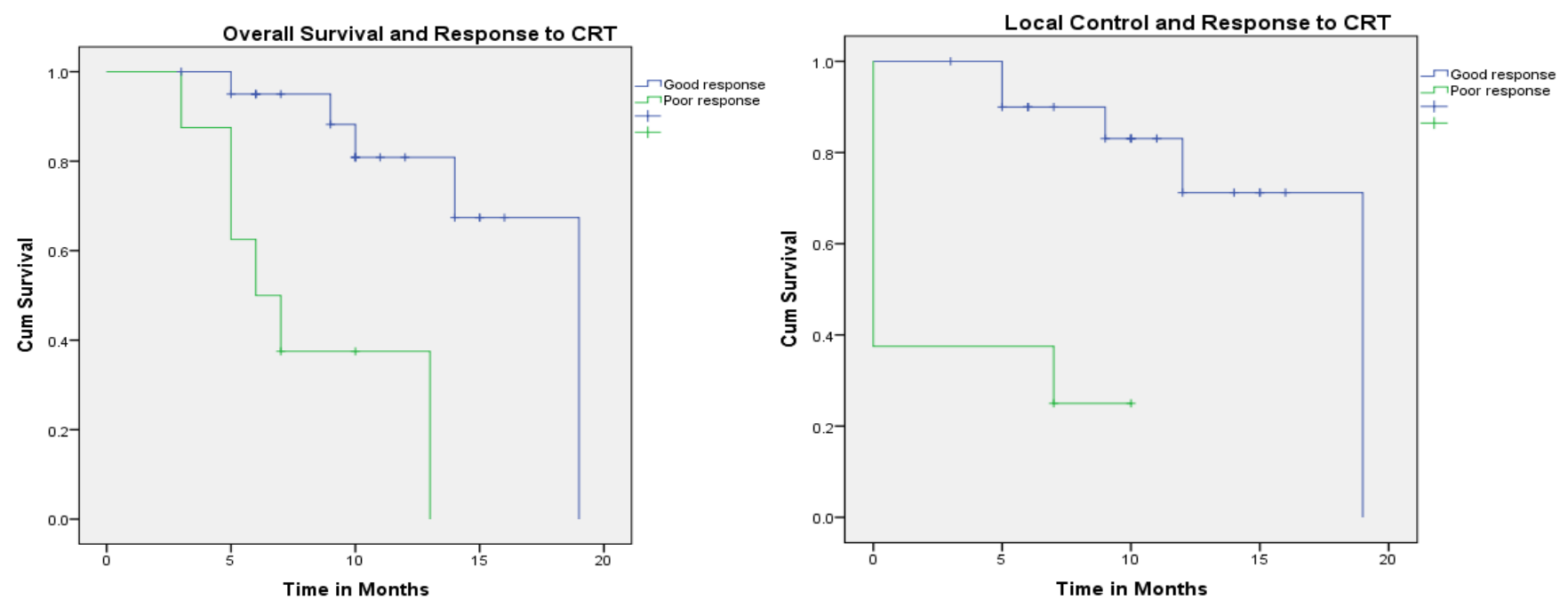

Fig 2A \& 2B. Kaplan Meier plots showing effect of Response to Chemoradiation on Overall Survival and Local Control 
Table 1: Patient and disease characteristics

\begin{tabular}{|l|c|}
\hline Variable & \\
\hline Age (mean) & $53.0 \mathrm{yrs}(30-70 \mathrm{yrs})$ \\
\hline Sex male & $23(76.6 \%)$ \\
\hline Length of disease (mean) & $6 \mathrm{~cm}(3-9 \mathrm{~cm})$ \\
\hline Thickness of disease (mean) & $1.3 \mathrm{~cm}(0.6-2.5 \mathrm{~cm})$ \\
\hline Initial weight loss (mean) & $6 \mathrm{~kg}$ \\
\hline Location of tumor Upper thorax & $1(3.3 \%)$ \\
Mid thorax & $24(80 \%)$ \\
Lower thorax & $5(16.7 \%)$ \\
\hline Number completing planned EBRT & $30(100 \%)$ \\
Number completing planned ILBT & $28(93.3 \%)$ \\
\hline Number completing 4 cycles of chemo & $21(70 \%)$ \\
\hline Response to chemoradiation :Good & $21(70 \%)$ \\
\hline
\end{tabular}

Table 2: Acute toxicity

\begin{tabular}{|c|c|}
\hline Toxicity & Incidence \\
\hline \begin{tabular}{cc}
\multicolumn{2}{l}{ Vomiting } \\
$\bullet$ & Grade 2 \\
$\bullet$ & Grade 3 \\
\end{tabular} & $\begin{array}{c}3(10 \%) \\
0 \\
\end{array}$ \\
\hline $\begin{array}{cc}\text { Anemia } & \\
\bullet & \text { Grade } 2(8-10 \mathrm{mg} / \mathrm{dl}) \\
\bullet & \text { Grade } 3(6.5-8 \mathrm{mg} / \mathrm{dl}) \\
\end{array}$ & $\begin{array}{c}1(3.3 \%) \\
0\end{array}$ \\
\hline $\begin{array}{cc}\text { Leucopenia } \\
\qquad \quad \text { Grade } 2(3000-2000) \\
\text { - } \quad \text { Grade } 3(2000-1000) \\
\end{array}$ & $\begin{array}{c}5(16.7 \%) \\
1(3.3 \%)\end{array}$ \\
\hline $\begin{array}{l}\text { Elevated Creatinine } \\
\text { • } \quad \text { Grade } 2(1.8-3.6 \mathrm{mg} / \mathrm{dl})\end{array}$ & $1(3.3 \%)$ \\
\hline $\begin{array}{cc}\text { Esophagitis } \\
\bullet & \text { Grade } 2 \\
\bullet & \text { Grade } 3 \\
\end{array}$ & $\begin{array}{c}7(23.3 \%) \\
1(3.3 \%) \\
\end{array}$ \\
\hline \begin{aligned} & \multicolumn{2}{l}{ Infection } \\
&\[ \] Herpes zoster \\
&$\bullet$ Pneumonia \\
&\end{aligned} & $\begin{array}{l}1(3.3 \%) \\
2(6.7 \%)\end{array}$ \\
\hline
\end{tabular}

Table 3: Late sequlae

\begin{tabular}{|l|c|}
\hline \multicolumn{1}{|c|}{ Late toxicity } & Incidence \\
\hline $\begin{array}{l}\text { Ulceration } \\
\text { Symptomatic }\end{array}$ & $2(6.7 \%)$ \\
\hline Stricture & $3(10 \%)$ \\
Grade 2 & $1(3.3 \%)$ \\
Grade 3 & $2(6.7 \%)$ \\
\hline Esophageal perforation & $1(3.3 \%)$ \\
With gross disease & $6(20 \%)$ \\
\hline Without disease & Cardiac toxicity \\
Grade 1 & $4(13.3 \%)$ \\
\hline $\begin{array}{l}\text { Pulmonary toxicity } \\
\text { Grade 1 }\end{array}$ \\
\hline
\end{tabular}

Table 4: Comparison of late toxicity

\begin{tabular}{|l|c|c|c|c|}
\hline & $\begin{array}{c}\text { RTOG-9207 } \\
(10) \\
\mathrm{n}=50\end{array}$ & $\begin{array}{c}\text { Yorozu } \\
\text { et al (13) } \\
\mathrm{n}=53\end{array}$ & $\begin{array}{c}\text { Calais G et } \\
\text { al (11) } \\
\mathrm{n}=53\end{array}$ & $\begin{array}{c}\text { Present study } \\
\mathrm{n}=30\end{array}$ \\
\hline $\begin{array}{c}\text { Ulceration } \\
\text { Symptomatic }\end{array}$ & $2 \%$ & $8 \%$ & $\mathrm{NA}$ & $6.7 \%$ \\
\hline $\begin{array}{c}\text { Stricture } \\
\text { Grade 3 }\end{array}$ & $4 \%$ & $6 \%$ & $14 \%$ & $3.3 \%$ \\
\hline $\begin{array}{l}\text { Fistula } \\
\text { With disease }\end{array}$ & $6 \%$ & $10 \%$ & $4 \%$ & $6.7 \%$ \\
Without disease & $6 \%$ & $2 \%$ & 0 & $3.3 \%$ \\
\hline
\end{tabular}


Table 5: Comparison of local control and survival

\begin{tabular}{|l|c|c|c|c|}
\hline & $\begin{array}{c}\text { RTOG } \\
9207(10) \\
\mathrm{n}=50\end{array}$ & $\begin{array}{c}\text { Yorozu } \\
\text { et al (13) } \\
\mathrm{n}=53\end{array}$ & $\begin{array}{c}\text { Calais G } \\
\text { et al (11) } \\
\mathrm{n}=52\end{array}$ & $\begin{array}{c}\text { Present } \\
\text { study } \\
\mathrm{n}=30\end{array}$ \\
\hline Complete response & $73 \%$ & $\mathrm{NA}$ & $\mathrm{NA}$ & $70 \%$ \\
\hline Local control & $58 \%$ & $60 \%$ & $57 \%(3 \mathrm{yr})$ & $\begin{array}{c}61.7 \% \\
(1 \mathrm{yr}))\end{array}$ \\
\hline Overall survival & $48 \%(1 \mathrm{yr})$ & $\begin{array}{c}42 \%(2 \mathrm{yr}) \\
34 \%(5 \mathrm{yr})\end{array}$ & $\begin{array}{c}27 \%(3 \mathrm{yr}) \\
18 \%(5 \mathrm{yr})\end{array}$ & $74.8 \%(1 \mathrm{yr})$ \\
\hline
\end{tabular}

\section{Discussion}

Based on the RTOG 85-01 trial and the Cochrane review of 15 randomized trials concurrent chemoradiation became recognized as the standard in the radical treatment of carcinoma esophagus, especially in inoperable cases ${ }^{(8,9)}$. An analysis of the pattern of failure in these trials however revealed that a high proportion of patients (46-56\%) had persistent disease or a recurrence locally. Radiation dose escalation was attempted using external radiation or as brachytherapy boost. Dose escalation by external radiation was attempted in the INT 0123 trial, which however concluded that there is no increase in survival or local control with higher dose ${ }^{(4)}$. Analysis of patterns of failure shows lower loco regional failures, but more deaths due to treatment related toxicities and intercurrent illness in the high dose arm. Higher doses to critical structures like heart and lung may contribute to this.

Brachytherapy for dose escalation has been attempted in a few studies ${ }^{(10-13)}$. A comparison with these trials shows a similar trend in acute and late toxicities as well as local control (Table4). The treatment compliance was very good, with all patients completing external radiation and $70 \%$ of them receiving at least 4 cycles of weekly chemotherapy. Twenty-eight (93\%) patients received the planned brachytherapy also. This is in contrast to the RTOG 92-07 trial and study by Yorozu et al, where only $70 \%$ were able to complete the external radiation, ILBT and at least 2 cycles of chemotherapy ${ }^{(7,13)}$. The one year overall survival also compares favourably with the other similar studies (Table5).
In this study patients who had a good response to external radiation as assessed by endoscopy at the time of brachytherapy, had a significantly better local control and overall survival. Similar conclusion was also drawn in the study by Tessa et al. which showed that patients who had a complete response had a 5year survival of $65 \%{ }^{(12)}$. These results should be read in the context of trials of neoadjuvant chemoradiation which have questioned the role of surgery ${ }^{(5,6,14)}$. While surgery improves the local control, there was no survival benefit. In the recent CROSS trial also, $49 \%$ of patients with Squamous cell carcinoma had a complete pathological response, for whom surgery might not have been necessary ${ }^{(3)}$. Therefore, some clinicians recommend definitive chemoradiation, with surgery reserved for non-responders ${ }^{(14)}$.

However, clinical evaluation does not correlate well with pathological complete response ${ }^{(15)}$, and patients with Squamous cell carcinoma histology are known to develop late recurrences ${ }^{(16)}$.

Ongoing and Future trials

In view of evaluating the necessity of esophagectomy in all patients, the Surgery As Needed approach in Oesophageal cancer (SANO) trial is being proposed. The PreSANO trial with aim to determine the accuracy of detecting the presence or absence of residual disease after neoadjuvant chemoradiation is now ongoing ${ }^{(17)}$.

\section{Limitations of the study}

Endoscopic ultrasound which is the present standard in assessing tumor thickness and stage, and also nodal stage was not used in the pretreatment evaluation due to the lack of such 
facilities in the institution. The number of patients is small, to result in a meaningful conclusion. Also the period of follow-up is short, and may result is under reporting of local recurrences and over-estimation of survival.

\section{Conclusion}

In patients with Squamous cell carcinoma of the esophagus, radical chemoradiation with brachytherapy boost is well tolerated, with low incidence of severe complications and offers good survival.

\section{Bibliography}

1. Ferlay J, Soerjomataram I, Ervik M, Dikshit R, Eser S, Mathers C, Rebelo M, Parkin DM, Forman D, Bray F. GLOBOCAN 2012 v1.0, Cancer Incidence and Mortality Worldwide: IARC CancerBase No. 11 [Internet]. Lyon, France: International Agency for Research on Cancer. 2013 [cited 2018 Jan 17]. Available from: http://globocan.iarc.fr/

2. Samarasam. Esophageal cancer in India: Current status and future perspectives. Int J Adv Med Heal Res [Internet]. 2017 [cited 2018 Jan 17];4(1):5. Available from: http://www.ijamhrjournal.org/article.asp?is $\mathrm{sn}=2349$ -

4220; year $=2017$; volume $=4$; issue $=1$; spage

$=5 ;$ epage $=10 ;$ aulast $=$ Samarasam\#ref 23

3. van Hagen $P$, Hulshof MCCM, van Lanschot JJB, Steyerberg EW, Henegouwen MI van B, Wijnhoven BPL, et al. Preoperative Chemoradiotherapy for Esophageal or Junctional Cancer. N Engl J Med [Internet]. 2012;366(22):2074-84. Available from: http://www.nejm.org/doi/10.1056/NEJMoa 1112088

4. Minsky BD, Pajak TF, Ginsberg RJ, Pisansky TM, Martenson J, Komaki R, et al. INT 0123 (Radiation Therapy Oncology Group 94-05) Phase III Trial of Combined-Modality Therapy for
Esophageal Cancer: High-Dose Versus Standard-Dose Radiation Therapy. J Clin Oncol [Internet]. 2002 Mar [cited 2018 Mar 14];20(5):1167-74. Available from: http://ascopubs.org/doi/10.1200/JCO.2002. 20.5.1167

5. Stahl M, Stuschke M, Lehmann N, Meyer H-J, Walz MK, Seeber S, et al. Chemoradiation With and Without Surgery in Patients With Locally Advanced Squamous Cell Carcinoma of the Esophagus. J Clin Oncol [Internet]. 2005 Apr [cited 2018 Jan 15];23(10):2310-7. Available from: http://ascopubs.org/doi/10.1200/JCO.2005. 00.034

6. Bedenne L, Michel P, Bouché O, Milan C, Mariette C, Conroy $\mathrm{T}$, et al. Chemoradiation Followed by Surgery Compared With Chemoradiation Alone in Squamous Cancer of the Esophagus: FFCD 9102. J Clin Oncol [Internet]. 2007 Apr [cited 2018 Jan 15];25(10):1160-8. Available from: http://ascopubs.org/doi/10.1200/JCO.2005. 04.7118

7. Gaspar LE, Qian C, Kocha WI, Coia LR, Herskovic A, Graham M. A phase I/II study of external beam radiation, brachytherapy and concurrent chemotherapy in localized cancer of the esophagus (RTOG 92-07): Preliminary toxicity report. Int $\mathbf{J}$ Radiat Oncol Biol Phys. 1997;37(3):593-9.

8. Cooper JS, Guo MD, Herskovic A, Macdonald JS, Martenson JA, Byhardt R, et al. Chemoradiotherapy of Locally Advanced. 1999;281(17):1623-7.

9. Wong RKS, Malthaner R. Combined chemotherapy and radiotherapy (without surgery) compared with radiotherapy alone in localized carcinoma of the esophagus. In: Cochrane Database of Systematic Reviews [Internet]. John Wiley \& Sons, Ltd; 2006. Available from: 
http://dx.doi.org/10.1002/14651858.cd002 092.pub2

10. Gaspar LE, Winter K, Kocha WI, Coia LR, Herskovic A, Graham M. A Phase I/II study of external beam radiation, brachytherapy, and concurrent chemotherapy for patients with localized carcinoma of the esophagus (Radiation Therapy Oncology Group Study 9207). Cancer [Internet]. 2000;88(5):988-95. Available from: http://dx.doi.org/10.1002/(sici)10970142(20000301)88:5\%3C988::aidcncr7\%3E3.0.co

11. Calais G, Dorval E, Louisot P, Bourlier P, Klein V, Chapet S, et al. Radiotherapy with high dose rate brachytherapy boost and concomitant chemotherapy for stages IIB and III esophageal carcinoma: Results of a pilot study. Int $\mathbf{J}$ Radiat Oncol Biol Phys. 1997;38(4):769-75.

12. Tessa M, Rotta P, Ragona R, Sola B, Grassini M, Nassisi D, et al. Concomitant chemotherapy and external radiotherapy plus brachytherapy for locally advanced esophageal cancer: results of a retrospective multicenter study. Tumori [Internet]. 2005;91(5):406-14. Available from:http://www.ncbi.nlm.nih.gov/pubme d/16459637

13. Yorozu A, Toya K, Dokiya T. Long-term results of concurrent chemoradiotherapy followed by high dose rate brachytherapy for T2-3 N0-1 M0 esophageal carcinoma. Esophagus [Internet]. 2006;3(1):1-5. Available from: http://dx.doi.org/10.1007/s10388-0060073-9

14. Czito BG, Palta M, Willett CG. Results of the FFCD 9901 Trial in Early-Stage Esophageal Carcinoma : Is It Really About Neoadjuvant Therapy? 2015;32(23):2398400 .
15. Cheedella NKS, Suzuki A, Xiao L, Hofstetter WL, Maru DM, Taketa T, et al. Association between clinical complete response and pathological complete response after preoperative chemoradiation in patients with gastroesophageal cancer: analysis in a large cohort. Ann Oncol [Internet]. 2013 May 1 [cited 2018 Jan 16];24(5):1262-6. Available from: https://academic.oup.com/annonc/articlelookup/doi/10.1093/annonc/mds617

16. Steffen T, Dietrich D, Schnider A, Kettelhack C, Huber O, Marti WR, et al. Recurrence Patterns and Long-Term Results After Induction Chemotherapy, Chemoradiotherapy, and Curative Surgery in Patients With Locally Advanced Esophageal Cancer. Ann Surg [Internet]. 2017 Jul 24 [cited 2018 Jan 16]; Available from:

http://www.ncbi.nlm.nih.gov/pubmed/287 42685

17. Noordman BJ, Shapiro J, Spaander MCW, Krishnadath KK, Noordman BJ. Accuracy of Detecting Residual Disease After Cross Neoadjuvant Chemoradiotherapy for Esophageal Cancer ( preSANO Trial ): JMIR Res Protoc. 2015 Jun 29;4(2):e79. doi: 10.2196/resprot.4320. 